\title{
Computational Combustion and Emission Analysis of Biodiesel in a Variable Compression Ratio Engine
}

\author{
Mohamed Al-Dawody ${ }^{a} b$ and S.K. Bhatti ${ }^{b}$ \\ ${ }^{a}$ Faculty of Engineering - University of Al-Qadisiyah-Iraq \\ ${ }^{b}$ Department of Mechanical Engineering - College of Engineering (A) /Andhra University -India
}

\author{
A R T I CLE INFO \\ Article history: \\ Received 15 September 2019 \\ Received in revised form 05 October 2019 \\ Accepted 10 October 2019
}

\section{Keywords: \\ Soybean biodiesel \\ Performance}

Emissions

CFD analysis

\begin{abstract}
A B S T R ACT
The aim of the present study is to analyse the combustion characteristics, performance and emission parameters of a variable compression ratio (VCR) diesel engine experimentally and numerically using soybean methyl ester (SME) biodiesel. Initially the engine is fed with diesel to capture the basic data, and then SME was tested as $20 \%$ blend (B20), as $40 \%$ blend (B40) and as pure bio-fuel (B100). The experimental investigations are followed by a computational combustion and emissions analysis of diesel engine which is done by using the CFD software (ANSYS FLUENT 13). The combustion, performance and emissions parameters are evaluated by operating the engine at four different compression ratios of 15,16 , 17.5 and 19 and varying the load from $0 \mathrm{~kW}$ to $4.4 \mathrm{~kW}$ with $1.1 \mathrm{~kW}$ step. It is observed that peak pressure is closer to TDC when SME blends is increased. SME blend has earlier combustion start because of the advancement in the injection timing, shorter delay time. Increasing mixing ratio of biodiesel is found to decrease BTE slightly and increases the BSFC. Remarkable decrease in UHC and CO emissions as the ratio of SME is increased due to the complete combustion of biodiesel with presence of more oxygen in the combustion chamber. The measured BSN for B20, B40, and B100 SME was less than that of diesel fuel by $20.44 \%, 35.78 \%$, and $48.3 \%$ respectively. It is inferred from the combustion analysis that as the compression ratio increases from 15 to 19 a decrease in smoke intensity, $\mathrm{UHC}$, and $\mathrm{CO}$, but it increases the emission of NOx. Both turbulent kinetic energy and turbulent dissipation rate were decreased as the percentage of SME increased by $10.84 \%$ and $2.01 \%$ respectively. The increase in compression ratio from 15 to 19 caused an increase in the peak pressure, density, combustion velocity, turbulence, peak temperature, NOx and a decrease in soot emissions. It can be assessed that the B20 SME is best suited to implement it into diesel engine without any effects. It has been founded from the results that 19 compression ratio has shown good performance and low emissions as compared to other compression ratios. The results obtained from the experimental investigation have been compared with the results of CFD analysis and are found to be in good agreement with each other with just slight deviation.
\end{abstract}

\section{Introduction}

For more than a century, the reciprocating internal combustion (IC) engines have been a dependable workhorse in a wide variety of applications that require mechanical motive power. From its inception in the late 1800 s till date, tremendous progress has been made in the performance, reliability and efficiency. It is a well-known fact that diesel engines have deep impact on the industrial economy, as they are used in heavy trucks, city transport buses, locomotives, electrical generators, farm equipments, underground mine equipments etc., because of their simple, robust construction coupled with high thermal efficiency and specific power output with high fuel economy. Increasingly tough emissions regulations coupled with fast -

\footnotetext{
* Corresponding author. Tel.: +964(0)7814136944.

E-mail address: Mohamed.aldawody@qu.edu.iq ( Mohamed Al-Dawody)
} 


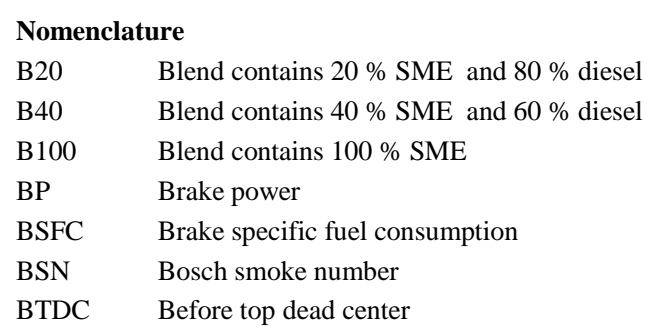

$\begin{array}{ll}{[\mathrm{C}]} & \text { Soot concentration in the cylinder } \\ \mathrm{CN} & \text { Fuel cetane number } \\ \mathrm{CO} & \text { Carbon monoxide } \\ \mathrm{UHC} & \text { Unburned hydrocarbons } \\ \mathrm{NOx} & \text { Oxides of nitrogen } \\ \mathrm{P} & \text { cylinder pressure } \\ \mathrm{PM} & \text { Particulate matter }\end{array}$

depleting crude oil resources have caused a stimulation of interest in finding alternative fuels for petroleum-based fuels like diesel and gasoline. For instance, on-road heavy-duty diesel engines face a stiff challenge in meeting the future standards for both NOx and PM emissions. However many researchers directed to search for alternative energy source [1-2]. All over the world, biodiesel is subjected to intensive research work. Biodiesel was found as the best alternate fuel, technically and environmentally acceptable, economically competitive and easily available. It has received much attention in the past decade due to its ability to replace fossil fuels, which are likely to run out within a century. Especially, the environmental issues concerned with the exhaust gases emission by the usage of fossil fuels also encourage the usage of biodiesel, which has proved to be ecofriendly far more than fossil fuels. It can be produced from various vegetable oils, waste cooking oils and animal fats via transesterification process together with methanol as well as $\mathrm{KOH}$ as a catalyst. Compared to original diesel fuel, it is reported that biodiesel has greater levels of cetane number, density, viscosity, but at the same time the calorific values of biofuel is 10 to 12 percent less than petroleum diesel [3]. The largest producers of soybeans are: United States, Brazil, Argentina, China and India [4]. The findings of many investigations have emphasized that while a promising reduction in the carbon emissions but at the same the emissions of NOx is increased as compared with neat diesel [5-21]. Although biofuel has a higher cetane number than diesel fuel but the bulk modulus in addition to viscosity have deep impact on the behavior of combustion of the fuel. The higher bulk modulus has been observed to contribute higher NOx production than neat diesel. The compressibility difference could lead to advance the injection timing hence, a greater chance to form NOx is expected $[22,23]$. The major reasons behind NOx emission are the start of injection, the time of peak heat release and peak temperature [24]. Same findings is reported by [25-28]. This research work is aimed to conduct experiments on a diesel engine powered by neat diesel and different volumetric blends of (SME). The experimental investigation is followed by a computational combustion and emissions analysis of diesel engine is done by using the CFD software ANSYS FLUENT 13

\section{Biodiesel Properties}

The soybean biodiesel under test is supplied from Intech energy systems Pvt. Ltd [29]. The production of soybean biofuel based on transesterification process. As seen in Table 1, all the properties of the biodiesel prepared meet the specifications required by ASTM D 6751-02 and EN14214. The schematic steps of biodiesel production is shown Fig.1

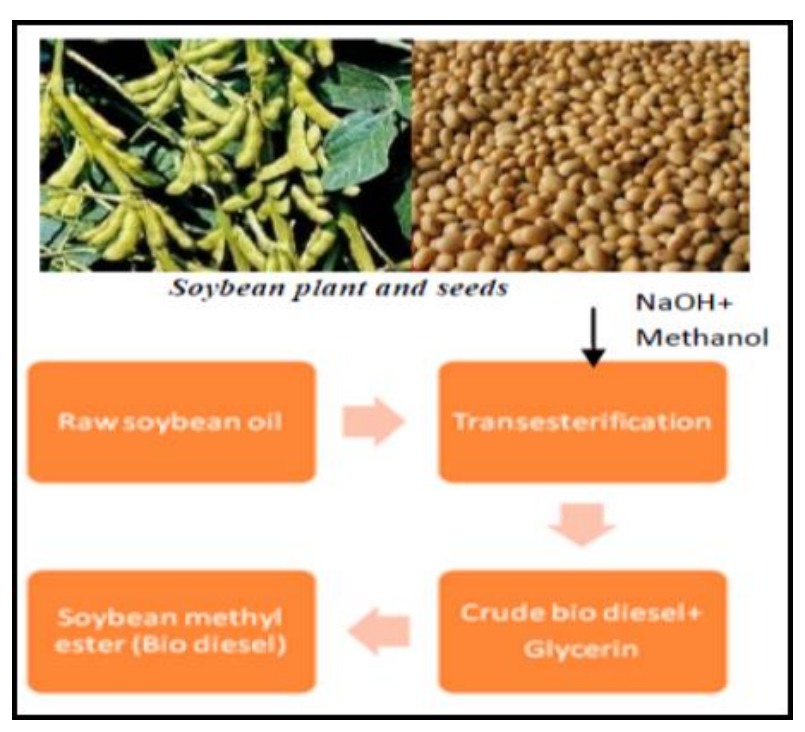

Figure 1 Steps of SME biodiesel production

Table 1, Diesel and SME biodiesel [29]

\begin{tabular}{|c|c|c|c|c|}
\hline Property & Diesel & B20\% SME & B40\% SME & SME \\
\hline $\begin{array}{l}\text { Chemical } \\
\text { formula }\end{array}$ & $\mathrm{C}_{13.77} \mathrm{H}_{23.44}$ & $\mathrm{C}_{14.97} \mathrm{H}_{26.33} \mathrm{O}_{0.34}$ & $\mathrm{C}_{16.07} \mathrm{H}_{28.94} \mathrm{O}_{0.68}$ & $\mathrm{C}_{19} \mathrm{H}_{35} \mathrm{O}_{2}$ \\
\hline $\begin{array}{l}\text { Density } \\
\left(\mathrm{kg} / \mathrm{m}^{3}\right)\end{array}$ & 830 & 841 & 852 & 876 \\
\hline $\begin{array}{l}\text { Viscosity } \\
\text { (cst) }\end{array}$ & 3.0 & 3.34 & 3.68 & 4.25 \\
\hline $\begin{array}{l}\text { Calorific } \\
\text { value } \\
(\mathbf{M J} / \mathbf{k g})\end{array}$ & 42.5 & 41.18 & 39.89 & 36.22 \\
\hline $\begin{array}{l}\text { Flash point } \\
\left({ }^{\circ} \mathrm{C}\right)\end{array}$ & 76 & 86.8 & 97.6 & 130 \\
\hline $\begin{array}{l}\text { Cetane } \\
\text { number }\end{array}$ & 48 & 48.69 & 49.37 & 51.3 \\
\hline
\end{tabular}

\section{Experimental Investigation}

The Kirloskar TAF-1, single cylinder, air cooled, variable compression ratio and direct injection diesel engine is used in this work. The technical specifications of the engine are given in Table 2. The actual photos of the engine and its attachments are shown in Figs.(2-3). Table 3 shows accuracy of smoke meter and gas analyzer as well along with their range of operation. 
Table 2, Specifications of engine

\begin{tabular}{cc}
\hline Engine Make & Kirloskar TAF-1 \\
\hline Engine Type. & 4-Stroke, Diesel Engine \\
Number of Cylinder & 1 \\
Bore $\times$ stroke & $87.5 \times 110 \mathrm{~mm}$ \\
Cylinder capacity & $0.66 \mathrm{~L}$ \\
Compression ratio & Variable $(15,16,17.5,19)$ \\
Rated power & $4.4 \mathrm{~kW}, 1500 \mathrm{rpm}$ \\
Maximum torque & $28 \mathrm{~N} . \mathrm{m}, 1500 \mathrm{rpm}$ \\
Orifice diameter & $0.15 \mathrm{~mm}$ \\
Injection timing & $20^{\circ} \mathrm{BTDC}$ \\
Injection pressure & $220 \mathrm{bar}$ \\
\hline
\end{tabular}

Table 3, The operating ranges and accuracies

\begin{tabular}{lll}
\hline Emission & Range & Accuracy \\
\hline $\mathrm{CO}$ & $0-10 \% \mathrm{vol}$ & $\pm 0.2 \%$ \\
$\mathrm{CO}_{2}$ & $0-20 \% \mathrm{vol}$ & $\pm 1 \%$ \\
$\mathrm{UHC}$ & $0-20000 \mathrm{ppm}$ & $\pm 10 \mathrm{ppm}$ \\
$\mathrm{O}_{2}$ & $0-22 \% \mathrm{vol}$ & $\pm 0.2 \%$ \\
$\mathrm{NOx}$ & $0-5000 \mathrm{ppm}$ & $\pm 10 \mathrm{ppm}$ \\
Opacity & $0-100 \%$ & $\pm 1 \%$ \\
\hline
\end{tabular}

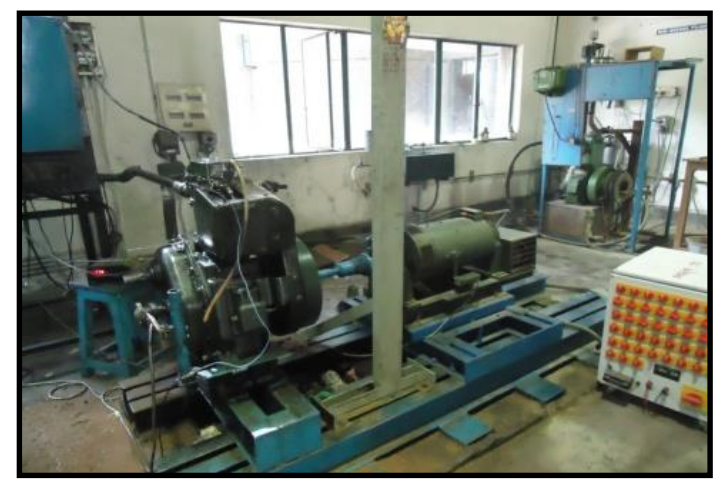

Figure 2 The actual photo of the engine test

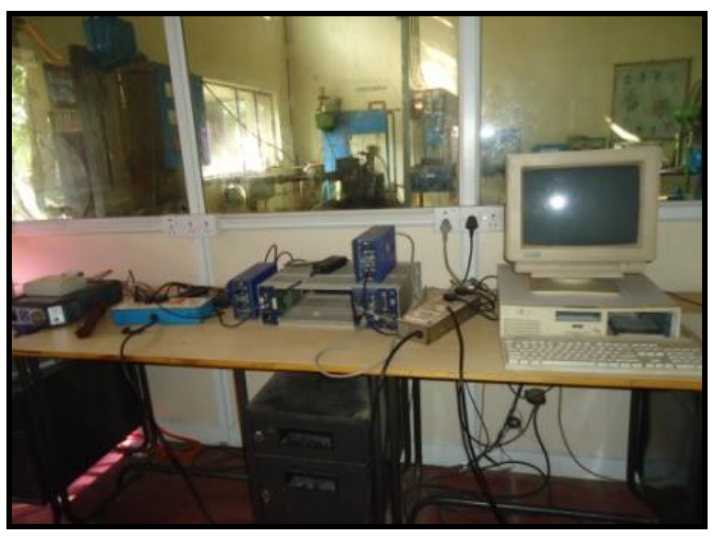

Figure 3 The computer system attached to the test rig

\section{Computation Model Analysis}

In the present work, a standard finite-volume CFD code, ANSYS FLUENT 13 which is frequently used in automotive engineering because of its superior meshing generation, pre- and post- processing, as well as the availability of user supports has been used to simulate the combustion process of variable compression ratio diesel engine working on SME-diesel blends. ANSYS FLUENT 13 solves the three-dimensional Navier-Stokes equations for a diesel engine. A choice of standard $\mathrm{k}$ - model is added to for describing turbulence effect. Sub-models are added for, ignition, turbulence-chemistry interactions and pollutant formation prediction.

\subsection{Turbulence Model}

The standard $k$ - $\varepsilon$ model is a semi-empirical model based on model transport equations. In the derivation of the k- $\varepsilon$ model, the assumption is that the flow is fully turbulent, and the effects of molecular viscosity are negligible (Launder B. et al [30]). The turbulence kinetic energy, $\mathrm{k}$ and its rate of dissipation $\varepsilon$, are obtained from the following transport equations [31]:

$$
\begin{aligned}
& \frac{\partial}{\partial t}(\rho k)+\frac{\partial}{\partial x_{i}}\left(\rho u_{i} k\right)=\frac{\partial}{\partial x_{j}}\left[\left(\mu+\frac{\mu_{t}}{\sigma_{k}}\right) \frac{\partial k}{\partial x_{j}}\right]+G_{k}+G_{b}-\rho \varepsilon-Y_{M}+S_{k} \\
& \frac{\partial}{\partial t}(\rho \varepsilon)+\frac{\partial}{\partial x_{i}}\left(\rho u_{i} \varepsilon\right)=\frac{\partial}{\partial x_{j}}\left[\left(\mu+\frac{\mu_{t}}{\sigma_{\varepsilon}}\right) \frac{\partial \varepsilon}{\partial x_{j}}\right]+C_{1 \varepsilon} \frac{\varepsilon}{k}\left(G_{k}+C_{3 \varepsilon} G_{b}\right)-C_{2 \varepsilon} \rho \frac{\varepsilon^{2}}{k}+S_{\varepsilon}
\end{aligned}
$$

\subsection{Combustion Model}

Seven combustion species are considered, fuel, $\mathrm{N}_{2}, \mathrm{O}_{2}, \mathrm{CO}, \mathrm{H}_{2} \mathrm{O}, \mathrm{H}_{2}$ and $\mathrm{CO}_{2}$. The time rate of change of the concentration of species $i$ is given by (Yashuhiro K. et al [32])

$\frac{d Y_{i}}{d t}=\left(Y_{i}-Y_{i}^{*}\right) / \tau_{c}$

$\tau_{c}=\tau_{l}+f \tau_{t}$

The variable $f$ can be considered as a coefficient that explains the effect of turbulence on combustion (Kong SC. et al [33])., hence $f$ is zero, before combustion and equals one when combustion completes. The laminar timescale is derived from a one step kinetic reaction rate as [31]:

$\tau_{l}=A^{-1}\left[C_{n} H_{2 n+2}\right]^{0.75}\left[O_{2}\right]^{-1.5} \exp (E / R T)$

The turbulent time scale is based on the eddy breakup concept and modeled as;

$\tau_{t}=C_{m 2} k / \varepsilon$

$C_{\mathrm{m} 2}$ model constant for mixing characteristics in the engine. The local mass fraction of each species $Y_{i}$, is predicted through the solution of a convection-diffusion equation for the $m_{t h}$ species i.e.,

$\frac{\partial\left(\rho Y_{i}\right)}{\partial t}+\nabla\left(\rho v^{\prime} Y_{i}\right)=-\nabla J_{i}+R_{i}+S_{i}$ 


\subsection{NOx Model}

In this work thermal and prompt models have been used [30]. The mechanisms of thermal and prompt NOx, the NO species transport equation is just required:

$\frac{\partial}{\partial t}\left(\rho Y_{N O}\right)+\nabla \cdot\left(\rho v \rightarrow Y_{N O}\right)=\nabla \cdot\left(\rho D \nabla Y_{N O}\right)+S_{N O}$

\subsubsection{Thermal NOx Model}

The principal reactions governing the formation of thermal NOx from molecular nitrogen are as follows:

$$
\begin{aligned}
& O+N_{2} \leftrightarrow N+N O \\
& N+O_{2} \leftrightarrow O+N O \\
& N+O H \leftrightarrow H+N O
\end{aligned}
$$

The NO formation rate becomes [30];

$$
\frac{d[N O]}{d t}=2 k_{f, 1}[O] \cdot\left[N_{2}\right] \frac{\left(1-\frac{k_{r, 1} k_{r, 2}[N O]^{2}}{k_{f, 1}\left[N_{2}\right] k_{f, 2}\left[O_{2}\right]}\right)}{\left(1+\frac{k_{r, 1}[N O]}{k_{f, 2}\left[O_{2}\right]+k_{f, 3}[O H]}\right)}
$$

\subsubsection{Prompt NOx Model}

The major contribution suggested as the prompt NOx source is from $\mathrm{CH}$ and $\mathrm{CH}_{2}$, is given by:

$$
\begin{aligned}
& \mathrm{CH}+\mathrm{N}_{2} \leftrightarrow \mathrm{HCN}+\mathrm{N} \\
& \mathrm{CH}_{2}+\mathrm{N}_{2} \leftrightarrow \mathrm{HCN}+\mathrm{NH}
\end{aligned}
$$

The prompt NOx formation rate can be approximately equal to the overall prompt NOx formation rate:

$$
\frac{d[N O]}{d t}=f k_{p r}^{\prime}\left[O_{2}\right]^{a}\left[N_{2}\right][F U E L] e^{-E_{a}^{\prime} / R T}
$$

Where $f$-correction factor which incorporates the effect of fuel type, i.e., number of carbon atoms, and air to fuel ratio which is given by;

$f=4.75+0.0819 n-23.2 \phi+32 \phi^{2}-12.2 \phi^{3}$

$k_{p r}^{\prime}=6.4 \times 10^{6}(R T / p)^{a+1}$

\subsection{Soot Model}

The one-step model predicted by [32] is used in this analysis

$\frac{\partial}{\partial t}\left(\rho Y_{\text {soot }}\right)+\nabla \cdot\left(\rho v^{\rightarrow} Y_{\text {soot }}\right)=\nabla \cdot\left(\frac{\mu_{t}}{\sigma_{\text {soot }}} \nabla Y_{\text {soot }}\right)+R_{\text {soot }}$

$R_{\text {soot }}$-net rate of soot generation, is the balance of soot formation $R_{\text {soot, form }}$ and soot oxidation $R_{\text {soot,comb }}$

$R_{\text {soot }}=R_{\text {soot,form }}-R_{\text {soot,comb }}$

The rate of soot formation is given by a simple empirical rate expression:

$$
R_{\text {soot form }}=C_{s} p_{f u e l} \phi^{r} e^{-E / R T}
$$

\subsection{CFD MODEL}

\subsubsection{Model Geometry and Mesh}

The CFD analysis investigated for combustion and emissions of SMEdiesel blends by replacing the percentage of SME blend. The blended fuel is injected at 220 bars. The inlet temperature of air is considered to be uniform at $300 \mathrm{~K}$. The combustion chamber was drawn using GAMBIT. The three dimensional model is based on was a virtual combustion chamber prototype at the end of compression stage. The valves and injector positioning can be understood with the help of Fig.4. Based on the varying compression ratio, the clearance volume changes but as the bore diameter remains the same, the height of the chamber has to be modified and new models have to be created for the analysis purpose. The height of the combustion chamber at the end of compression stroke is given for each compression ratio in Table 4. Application of the boundary conditions and meshing the combustion chamber are done using ICEM CFD by using a tetrahedral element. The mesh size for the model was considered as unity (1) .The total numbers of elements equal to 1157543 see Fig.5. The grid is refined in order to capture the boundary conditions specially in regions closer to nozzle.

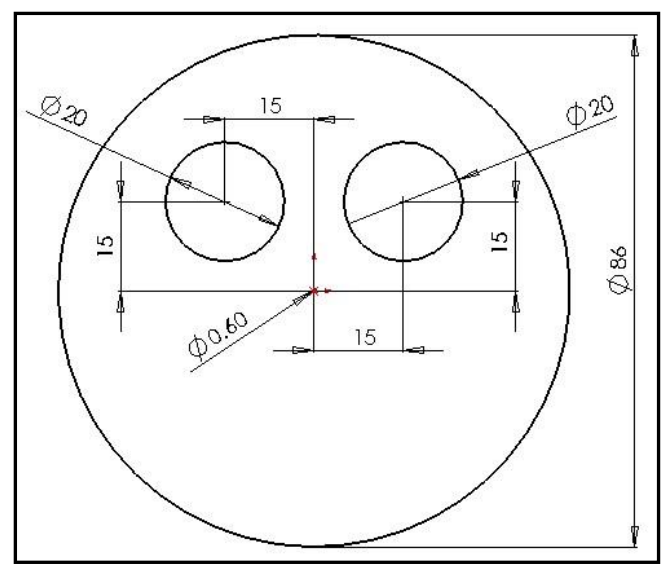

Figure 4 Positioning of nozzle and valves on cylinder head (dim. in mm)

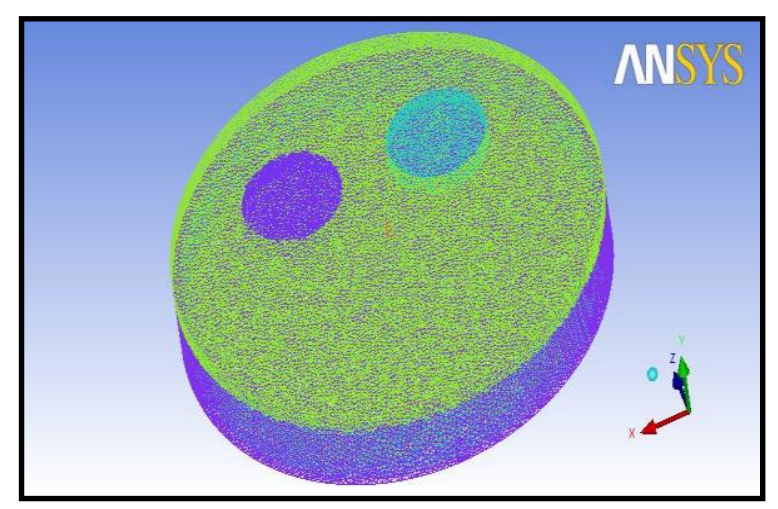

Figure 5 Computational model-grid mesh combustion chamber 
Table 4, Height of the chamber at different compression ratio

\begin{tabular}{lll}
\hline Compression ratio & $\begin{array}{l}\text { Clearance volume } \\
\left(\mathrm{mm}^{3}\right)\end{array}$ & Height $(\mathrm{mm})$ \\
\hline 15 & 47246.608 & 7.857 \\
16 & 44096.834 & 7.333 \\
17.5 & 40088.031 & 6.666 \\
19 & 36747.361 & 6.111 \\
\hline
\end{tabular}

\section{Results and Discussion}

Fig. 6 presents the pressure of cylinder verse crank angle for neat diesel and biodiesel. The cylinder pressure for biodiesel is lower than diesel by $2.98 \%$ due to the difference in the heating value for biodiesel. It is noted that the peak pressure for $\mathrm{B} 100 \mathrm{SME}$ is 78.246 bars at $6^{\circ}$ crank angle which comes neat to TDC than ordinary diesel where the maximum pressure was 80.65 bars at $9^{\circ}$ crank angle.

Fig. 7 shows the full load rate of heat release verse degree crank angle. the value of heat release rate is decreased when biodiesel blends increased. The message from this figure is that the biodiesel blend had an earlier start of combustion. The same observations are reported by [34-36].

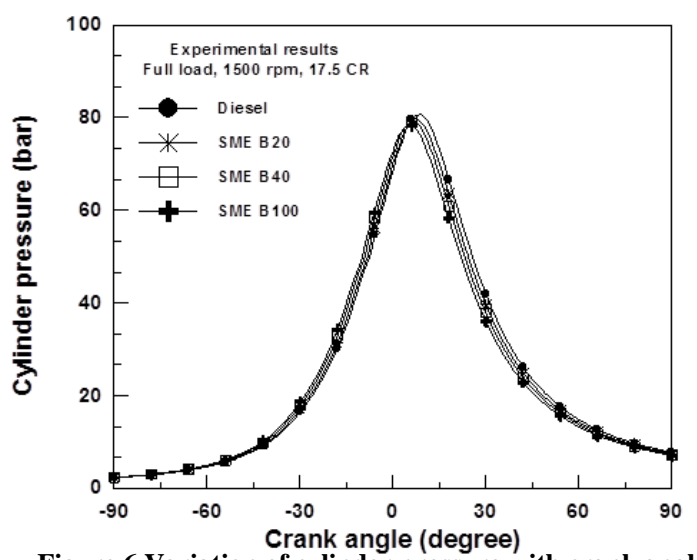

Figure 6 Variation of cylinder pressure with crank angle

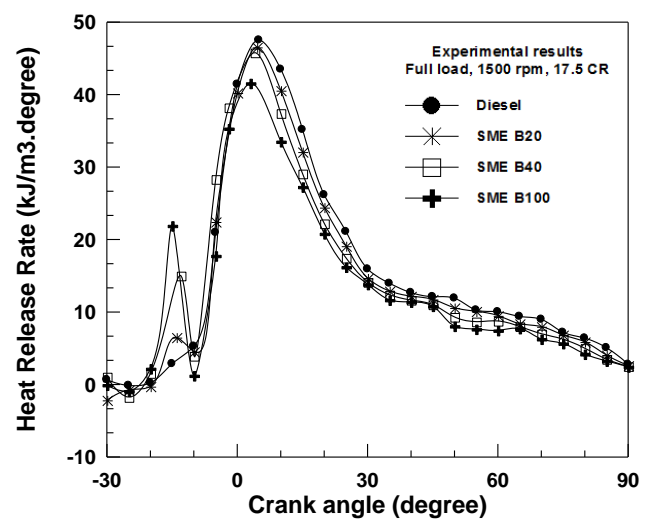

Figure 7 Variation of heat release rate with crank angle

BSFC results are presented in Fig.8 for different engine loads. The BSFC decreased as the engine load increased. This is because, the rate of increasing power is greater than consumption of fuel. While BSFC was calculated as $0.537 \mathrm{~kg} / \mathrm{kW}$ h with SME B20 at $1.1 \mathrm{~kW}$ load; it was found as $0.275 \mathrm{~kg} / \mathrm{kW}$ h at $4.4 \mathrm{~kW}$. The BSFC is increased with the increasing
SME percentage due to the higher viscosity and density with lower heating value of biodiesel compared to diesel fuel. At full load, BSFC for SME B20, SME B40, and SME B100 increased by $4.24 \%, 8.71 \%$, and $14.66 \%$ respectively. Fig. 9 displays BTE verse load. From the above discussion, it is concluded that BSFC is increased as the substitution of biodiesel is increased., BTE depends on BSFC and heat quantity as well. In general $\mathrm{BTE}$ is reduced as the blend ratio of SME is increased .

The result of UHC emissions are illustrated in Fig. 10 for different loads. Typically, (Sayin C. et al [37]). While UHC emission was measured to be $18 \mathrm{ppm}$ with diesel fuel at $0 \mathrm{~kW}$ load; it was $62 \mathrm{ppm}$ at $4.4 \mathrm{~kW}$. In Fig. 10 UHC emissions is decreasing with increase the substitution of .biodiesel. This belong to enough quantity of oxygen helps for complete combustion. UHC emissions for SME B20, SME B40, as well as SME B100 decreased by $15 \%, 27 \%$, and $38.4 \%$.

Generally, CO emissions are affected by air-fuel equivalence ratio, fuel type, combustion chamber design, and atomization rate, start of injection timing, injection pressure, compression ratio, engine load and speed.

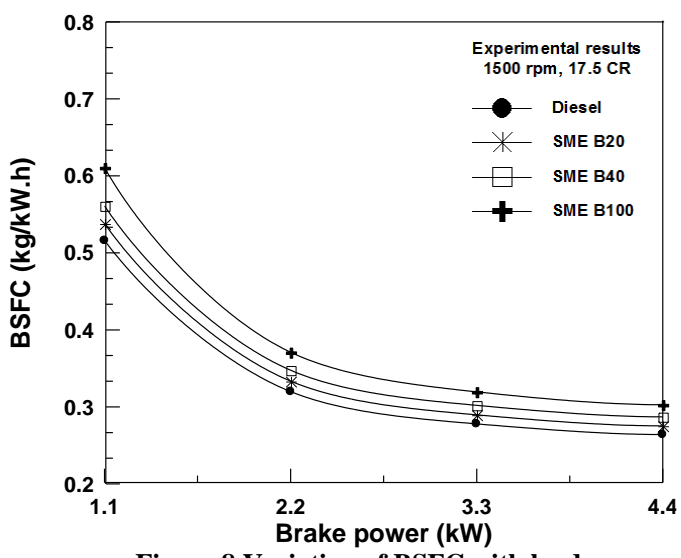

Figure 8 Variation of BSFC with load

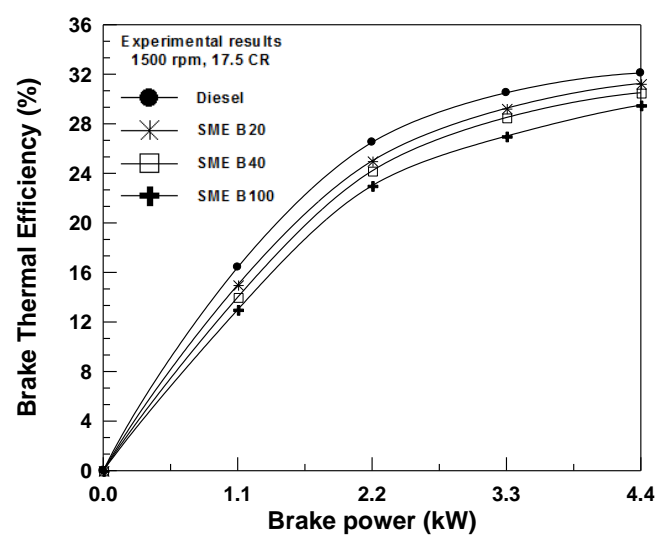

Figure 9 Variation of BTE with load

$\mathrm{CO}$ emission results are presented in Fig.11 for different engine loads. Lower $\mathrm{CO}$ emission is noticeable at part load while the higher one is noticed at full load. As the load increased, there is an increase in $\mathrm{CO}$ emissions and this is typical with all internal combustion engines since air-fuel ratio (A/F) decreases as the load increased (Ramadhas A. et al [38]). While CO emission was measured as 0.054 (\% vol) with B20 SME at $0 \mathrm{~kW}$ load; it was 0.195 (\% vol) at $4.4 \mathrm{~kW}$. CO emission is decreased when biodiesel percentage is increased. The oxygenated nature of biodiesel is responsible for that (Gumus M. [39]). For all engine loads, CO emissions for SME B20, 
SME B40, and SME B100 reduced by $11.36 \%, 29.1 \%$, and $41.7 \%$ compared to that of diesel fuel, respectively. The reduction of NOx emissions are always the target for engine researchers and manufacturers. Three conditions which favor NOx formation are: higher combustion temperature, more oxygen content and faster reaction rate (Hiroyasu et al [40]).

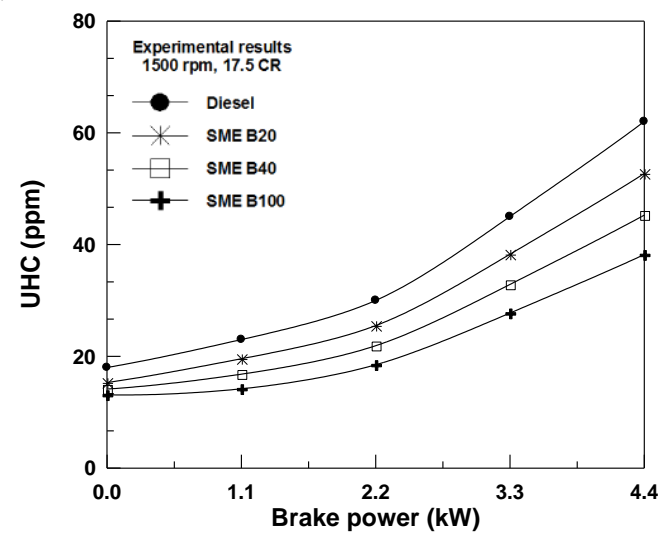

Figure 10 Variation of UHC emissions with load

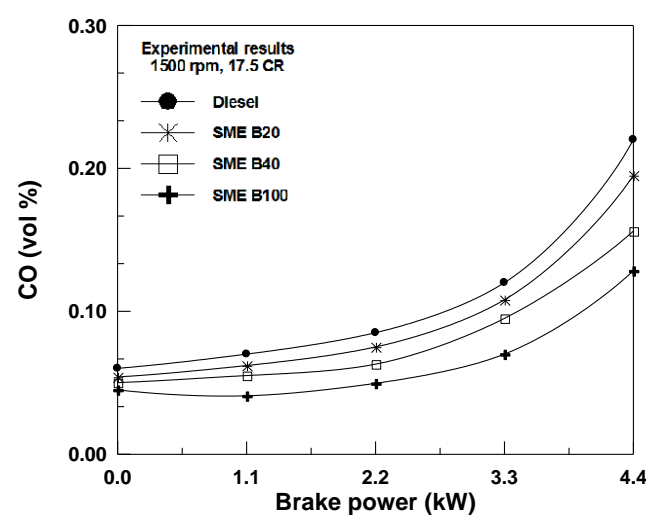

Figure 11 Variation of $\mathrm{CO}$ emissions with load

NOx emissions results are presented in Fig.12 for different engine loads. The NOx emissions increased as the engine load increased, due to the increase in combustion temperature. The emission of NOx increased with the increasing biodiesel blend ratio. The oxygenated nature of SME biodiesel increases NOx emission. Same results is highlighted by (Ozsezen A. et al [41]) and (Lapuerta M. et al [42]).

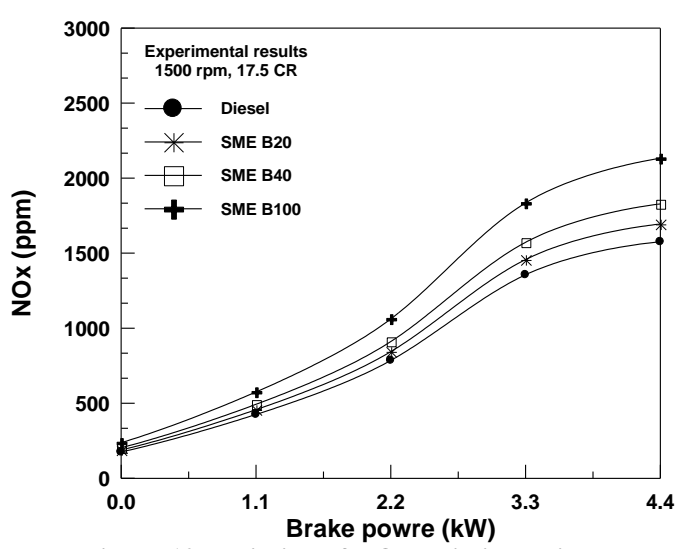

Figure 12 Variation of NOx emissions with load
The results of smoke emission were depicted in Fig. 13 for different engine loads. The smoke emission increased with the increase in the brake power. The formation of smoke strongly depends on the engine load. As the load increases, more fuel is injected, and this increases smoke formation (Metin G. et al [43]). While Bosch smoke number (BSN) was measured to be 0.425 with diesel fuel at $4.4 \mathrm{~kW}$, it was 0.3381 for SME B20\% at $4.4 \mathrm{~kW}$ for 17.5 optimum compression ratio.

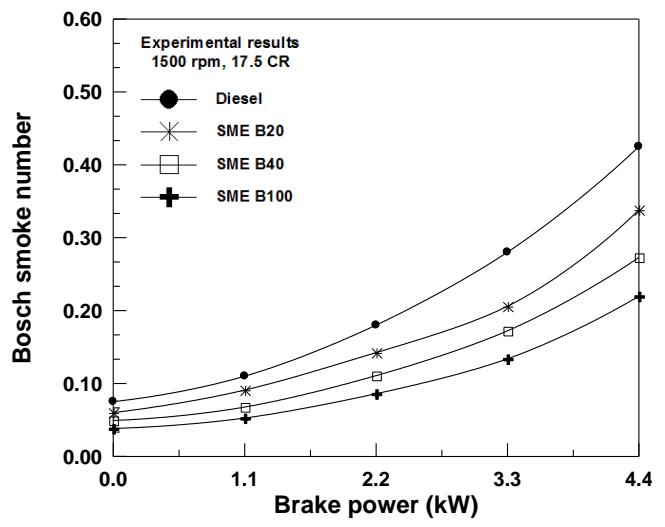

Figure 13 Variation of BSN with load

As illustrated in Fig. 13, the smoke starts to decrease as the percentage of biodiesel increased in the fuel blend. It is mentioned that smoke decreases with high oxygen content in the biodiesel. For all engine loads, the BSN for SME B20, SME B40, and SME decreased by $20.44 \%$, 35.78\%, and $48.31 \%$, compared to those of diesel, respectively. Same observations are noted in the result of (Monyem A.[44]). Fig. 14(a-d) shows pressure, velocity, turbulent kinetic energy and dissipation rate contours for B20 SME respectively. Theoretically the pressure is maximum at the core and decreases towards the periphery. But when flame fronts strike the cylinder walls, negative flame fronts are formed resulting in formation of localized high pressure areas near the cylinder walls as shown in Fig. 14(a). Also it is observed that combustion pressure decreases with increase in SME blends. The maximum pressure for neat SME is less than that of diesel by $4.6 \%$ because of the heating values reduction for blended fuel.

The base of the combustion chamber is visible in the velocity contour plots. It is evident from Fig.14 (b) that the combustion velocity is higher near the fuel injector and decreases towards the cylinder walls. As the blending ratio of SME increased, the velocity decreased gradually because of higher viscosity and density of soybean biodiesel with respect to diesel fuel. The reduction in the combustion velocity is up to $6.72 \%$ as the blending ratio of SME increased from (0-100) \%.

Fuel-air mixing and combustion in reciprocating internal combustion engines are highly dependent on the in-cylinder turbulent flow. High turbulence results in improved mixing but the very high values of turbulence can cause knocking. Turbulence in the engine produces kinetic energy also known as turbulent kinetic energy (T.K.E). As seen in Fig.14(c) the T.K.E. maximum at the nozzle region and gradually decreases away from nozzle. T.K.E values reduced as a result of increase in the blend of soybean due to higher viscosity and density values of the blended fuel as compared to conventional diesel fuel. The average T.K.E is reduced by $4 \%$ $20 \%$ SME, $7.44 \%$ for $40 \%$ SME and 10.84 neat $100 \%$ biodiesel . 


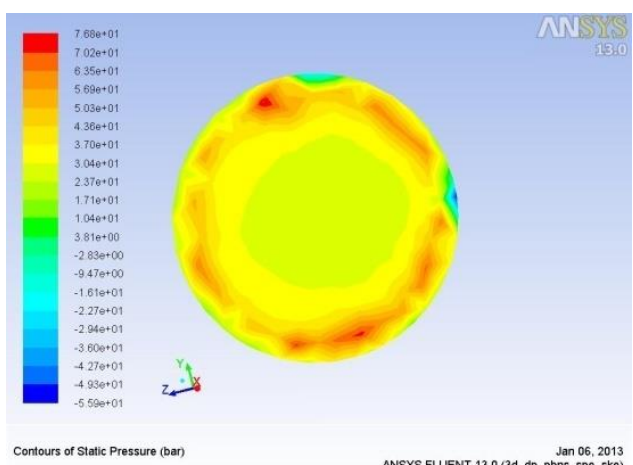

Figure 14(a) Pressure contour for B20 SME velocity

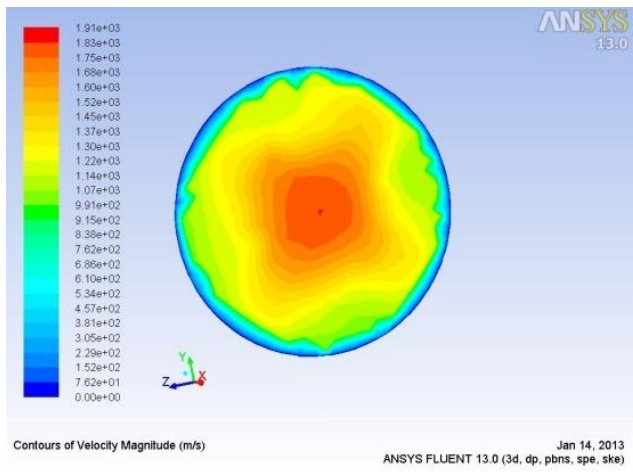

Figure 14(b) Velocity contour for B20 SME

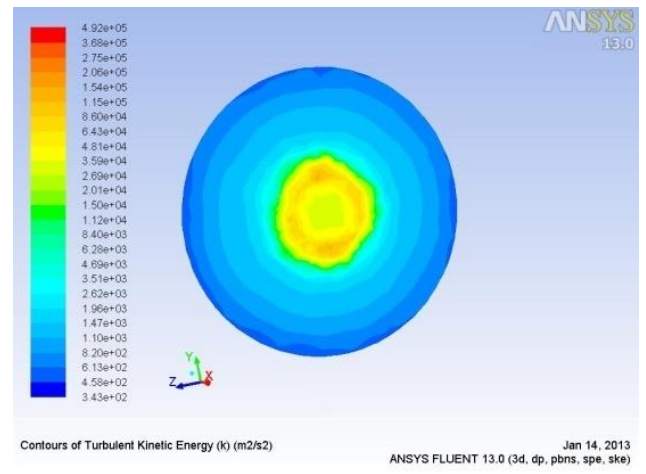

Figure 14(c) Turbulent kinetic energy contour for B20 SME

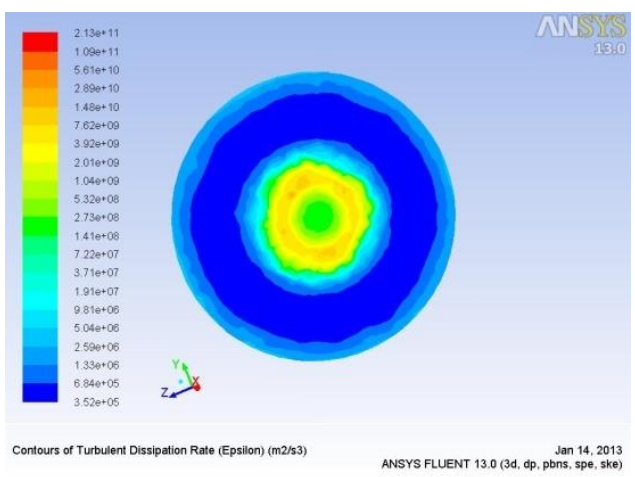

Figure 14(d) Turbulent dispassion rate contour for B20 SME
It can be observed from Fig. 14(d) that turbulent dissipation rate (T.D.R) increases in the nozzle region and it highly depends on the T.K.E. It promotes the rate of combustion. By increasing the percentage of SME blends causes a reduction in the rate of dissipation energy by $2 \%$.

Fig. 15(a-b) shows NOx and soot mass fraction contours for B20 SME respectively. It is noticed from Fig. 15(a) that peak NOx value increases near the wall due to the formation of localized high temperature areas near the combustion chamber walls. The NOx emissions for soybean biodiesel blends are higher than that of base line diesel fuel. This is related to the higher combustion temperature and higher oxygen content in the biodiesel as compared to diesel fuel which in turn enhanced NOx formation.

Fig. 15(b) shows the soot mass fractions for B20 SME. Soot levels for B20, $\mathrm{B} 40$, and B100 are less than diesel by $21.61 \%, 36.33 \%$, and $41.41 \%$ respectively. It is mentioned early that lower $\mathrm{C} / \mathrm{H}$ ratio together with high oxygen content of biodiesel are the main reasons of reducing soot formation

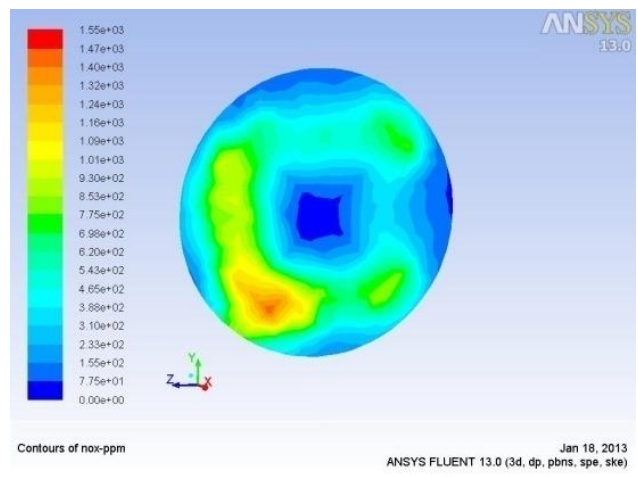

Figure 15(a) NOx emissions for B20 SME

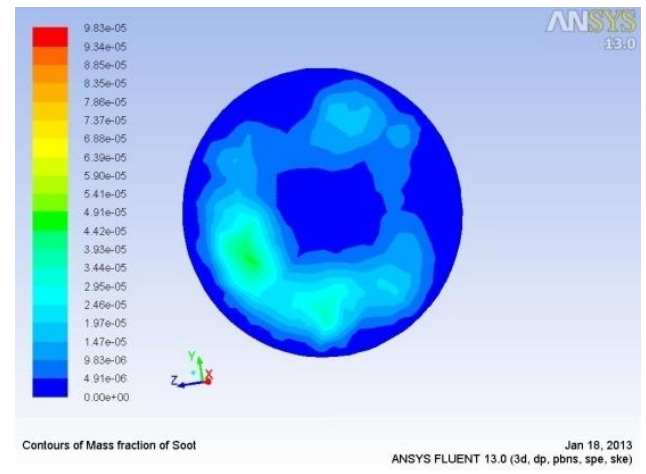

Figure 15(b) Soot emissions contour for B20 SME

\section{Verification}

The experimental investigation is compared with CFD analysis as shown in Table 5. The comparison between the two was found in good agreement with a slight difference. 
Table 5, Verification of results between diesel and B20 SME

\begin{tabular}{|c|c|c|c|c|c|c|c|}
\hline Fuel & $\begin{array}{l}\Delta \% \\
\text { Peak } \\
\text { Pres. }\end{array}$ & $\begin{array}{l}\Delta \% \\
\text { Peak } \\
\text { Temp }\end{array}$ & $\begin{array}{l}\Delta \% \\
\text { Veloc } \\
\text { ity }\end{array}$ & $\begin{array}{l}\Delta \% \\
\text { T.K.E }\end{array}$ & $\begin{array}{l}\Delta \% \\
\text { T. } \\
\text { D.R }\end{array}$ & $\begin{array}{l}\Delta \% \\
\text { NOx }\end{array}$ & $\begin{array}{l}\Delta \% \\
\text { Soot }\end{array}$ \\
\hline Diesel & - & - & - & - & - & - & - \\
\hline B20SME & -1.31 & +2.27 & -1.53 & -4 & +0.21 & +6 & -21.61 \\
\hline B40SME & -3.5 & +4.50 & -3.82 & -7.44 & -1.22 & +14.15 & -36.3 \\
\hline SME & -4.6 & +5.86 & -7.61 & -10.8 & -2 & +27.77 & -41.41 \\
\hline
\end{tabular}

\section{7. Conclusions}

\subsection{Conclusions from the Experimental Investigation}

1- Increasing load reported remarkable increase in pressure, brake efficiency and smoke while UHC as well as BSFC is decreased.

2- Earlier combustion start for all biodiesel blends.

3- BTE is slightly reduced and fuel consumption is increased when SME percentage increased

4- UHC is reduced with B100 \% SME by $38.4 \%$ as well as the emission of $\mathrm{CO}$ is decreased with $\mathrm{B} 100 \%$ SME $41.7 \%$ respectively.

5- The measured BSN for SME blends was less than that of neat diesel.

6- In terms of compression ratio, the test results demonstrated that, BSFC increased with the increased compression ratio.

\subsection{Conclusions from the CFD Analysis}

1.The combustion pressure reduced by $4.6 \%$ as a result of SME replacement from $(0-100) \%$.

2.The flame combustion temperatures are noticed to be higher for SME blends compared to original fuel (diesel).

3. Combustion velocity was reduced by $6.71 \%$ as the blending ratio of SME increased from $(0-100) \%$.

4. Both T.K.E and T.D.R were decreased as the percentage of SME increased by $10.84 \%$ and $2.01 \%$ respectively

5. B20 SME, B40 SME, and B100 SME produced significant reductions in the soot levels by $19.48 \%, 35.030 \%$, and $38.86 \%$ respectively compared with diesel fuel.

6. Increasing the compression ratio causes an increase in peak pressure, density, combustion velocity, turbulence, peak temperature, NOx and it caused to decrease soot emissions.

\section{REFERENCES}

[1] Yoon S, Lee C. Experimental investigation on the combustion and exhaust emission characteristics of biogas-biodiesel dual-fuel combustion in a CI engine. J Fuel Process Technol 2011;92:992-1000.

[2] Kim MY, Yoon SH, Hwang JW, Lee CS. Characteristics of particulate emissions of compression ignition engine fueled with biodiesel derived from soybean. J Eng Gas Turbine Power 2008;130:1-7.

[3] Oner C, Altun S. Biodiesel production from inedible animal tallow and an experimental investigation of its use as alternative fuel in a direct injection diesel engine. J Appl Energy 2009;86:2114-20.

[4] Roberto G, Oscar E, Valdir D, Dalni MM, Ednilton T. Use of soybean oil in energy generation. Recent Trends Enhancing Divers Qual Soybean Prod 2011:15-7.

[5] Zhang X, Gao G, Li L, Wu Z. Characteristics of combustion and emissions in a DI engine fueled with biodiesel blends from soybean oil, SAE 2008-011832.
[6] Labeckas G, Slavinskas S. The effect of rapeseed oil methyl ester on direct injection diesel engine performance and exhaust emissions. J Energy Convers Manage 2006;47:1954-67.

[7] Labeckas G, Slavinskas S. Performance and emission characteristics of a direct injection diesel engine operating on KDV synthetic diesel fuel. J Energy Convers Manage 2013;66:173-88.

[8] Canakci M. Performance and emissions characteristics of biodiesel from soybean oil. Proc Inst Mech Eng Part D: J. Automob Eng 2005;219:915-22.

[9] Ushakov S, Valland H. Combustion and emissions characteristics of fish oil fuel in a heavy-duty diesel engine. J Energy Convers Manage 2013;65:22838.

[10] Scholl K, Sorenson S. Combustion of soybean oil methyl ester in a direct injection diesel engine, SAE 930934; 1993.

[11] Rakopoulos CD, Antonopoulos KA, Rakopoulos DC. Development and application of multi-zone model for combustion and pollutants formation in direct injection diesel engine running with vegetable oil or its bio-diesel. J Energy Convers Manage 2007;48:1881-901.

[12] Buyukkaya E. Effects of biodiesel on a DI diesel engine performance, emission and combustion characteristics. J Fuel 2010;89:3099-0

biofuels. J Energy Convers Manage 2010;51:1714-8.

[13] Hamdan MA, Haj Khalil R. Simulation of compression engine powered by biofuels. J Energy Convers Manage 2010;51:1714-8.

[14] Masood M, Mehdi SN, Reddy P. Experimental investigations on a hydrogen- diesel dual fuel engine at different compression ratios. J Eng Gas Turbine Power 2007;129:572-8.

[15] Qi DH, Chen H, Geng LM, Bian YZH. Experimental studies on the combustion characteristics and performance of a direct injection engine fueled with biodiesel/diesel blends. J Energy Convers Manage 2010;51:2985-92.

[16] Rakopoulos CD, Antonopoulos KA, Rakopoulos DC, Hountalas DT. Multizone modeling of combustion and emissions formation in DI diesel engine operating on ethanol-diesel fuel blends. J Energy Convers Manage 2008;49:625-43.

[17] Gumus M, Kasifoglu S. Performance and emission evaluation of a compression ignition engine using a biodiesel (apricot seed kernel oil methyl ester) and its blends with diesel fuel. J Biomass Bioenergy 2010;34:134-9.

[18] Kannan D, Pachamuthu S, Nurun Md, Hustad JE, Lovas T. Theoretical and experimental investigation of diesel engine performance, combustion and emissions analysis fuelled with the blends of ethanol, diesel and jatropha methyl ester. J Energy Convers Manage 2012;53:322-31.

[19] Yuan W. Computational modeling of NOx emissions from biodiesel combustion based on accurate fuel properties, $\mathrm{PhD}$ thesis, Pennsylvania Avenue, Urbana; 2005.

[20] Rakopoulos CD, Hountalas DT, Giakoumis EG, Andritsakis EC. Performance and emissions of bus engine using blends of diesel fuel with bio-diesel of sunflower or cottonseed oils derived from Greek feedstock. J. Fuel 2008;87:147-57.

[21] Gokalp B, Buyukkaya E, Soyhan HS. Performance and emissions of a diesel tractor engine fueled with marine diesel and soybean methyl ester. $\mathrm{J}$ Biomass Bioenergy 2011;35:3575-83.

[22] Melissa Hess A, Michael Haas J, Foglia AT. Attempts to reduce NOx exhaust emissions by using reformulated biodiesel. J Fuel Process Technol 2007;88:693-9.

[23] Tat M, Gerpen V, Soylu S, Canakci M, Monyem A, Wormley S. The speed of sound and isentropic bulk modulus of biodiesel at $21 \mathrm{C}$ from atmospheric pressure to 35 MPa. JACS 2000;77:285-9.

[24] Agarwal D, Sinha S, Kumar A. Experimental investigation of control of NOx emissions in biodiesel-fueled compression ignition engine. J Renew Energy 2006;31:2356-69.

[25] Lei Zh, Cheung C, Zhanga WG. Influence of methanol-biodiesel blends on the particulate emissions of a direct injection diesel engine. J Aerosol Sci Technol 2010;44:362-9.

[26] Bryan Moser R, Williams A, Michael Haas J, Robert McCormick L. Exhaust emissions and fuel properties of partially hydrogenated soybean oil methyl esters blended with ultra low sulfur diesel fuel. J Fuel Process Technol 2009;90:1122-8. 
[27] Mueller J, Boehman AL. An experimental investigation of the origin of increased NOx emissions when fueling a heavy-duty compression-ignition engine with soy biodiesel. J SAE 2009:1792.

[28] Graboski M, McCormick R. Combustion of fat and vegetable oil derived fuels in diesel engines. J Prog Energy Combust Sci 1998;24:125-64.

[29] Intech Energy Systems Private Limited, available from http:// http://www.intechenergy.com/

[30] Launder B. E. and D. B. Spalding. "Lectures in Mathematical Models of Turbulence”. Academic Press, London, England, 1972.

[31] ANSYS FLUENT 12.0, Theory Guide, Copyright by ANSYS, Inc, 2009.

[32] Yashuhiro KT, Yuki SN, Ryoji K, Takeshi S. Controlling combustion and exhaust emissions in a direct-injection diesel engine dual fueled with natural gas. SAE paper No. 1995-952436, 1995

[33] Kong SC, Han ZW, Reitz RD. The development and application of a diesel ignition and combustion model for multidimensional engine simulations. SAE paper No. 1995- 950278, 1995.

[34] Ahmet N., Mustafa C. "Determination of performance and combustion characteristics of a diesel engine fueled with canola and waste palm oil methyl esters". Energy Conversion and Management, Vol. 52: pp. 108-116 (2011).

[35] Boehman AL, Morris D, Szybist J, Esen E. "The impact of the bulk modulus of diesel fuels on fuel injection timing”. Energy Fuel, Vol.18 pp. 1877-1882 (2004).

[36] Stringer FW, Clarke AE, Clarke JS. "The spontaneous ignition of hydrocarbon fuels in a flowing system". Proc Inst Mech Eng,Vol.184 pp. 212-225 (1970).
[37] Sayin C, Ilhan M, Canakci M, Gumus M. Effect of injection timing on the exhaust emissions of a diesel engine using diesel-methanol blends. Renew Energy, Vol.34 pp. 1261-1269 (2009).

[38] Ramadhas AS, Muraleedharan C, Jayaraj S. "Performance and emission evaluation of a diesel engine fueled with methyl esters of rubber seed oil". Renew Energy, Vol.30 pp.1789-1800 (2005).

[39] Gumus M. "Evaluation of hazelnut kernel oil of Turkish origin as alternative fuel in diesel engines". Renew Energy, Vol. 33 pp. 2448-2457 (2008).

[40] H.Hiroyasu, T. Kadota, "Models of Combustion and Formation of Nitric Oxide and Soot in DI Diesel Engines", SAE paper No. 760129, (1976).

[41] Ozsezen AN, Canakci M, Turkcan A, Sayin C. "Effects of Biodiesel from used frying palm oil on the performance, injection, and combustion characteristics of an indirect injection diesel engine”. Energy Fuels, Vol. 22 pp. 1297-305 (2008).

[42] Lapuerta M, Armas O, Fernandes JS. "Effect of biodiesel fuels on diesel engine emissions". Prog Energy Combust Sci, Vol.34 pp. 198-223 (2008).

[43] Metin G., Cenk S. , Mustafa C., "The impact of fuel injection pressure on the exhaust emissions of a direct injection diesel engine fueled with biodiesel-diesel fuel blends", Fuel, Vol.95 pp. 486-494 (2012).

[44] Monyem A. The effect of biodiesel oxidation on engine performance and emissions. Ph.D. Dissertation, Department of Mechanical Engineering, Iowa State University, Ames, IA; (1998). 